Article

\title{
Secularities, Diversities and Pluralities: Understanding the Challenges of Religious Diversity in Latin America
}

\author{
Edgar Zavala-Pelayo * and Manuel Góngora-Mera \\ Lateinamerika-Institut, Freie Universität Berlin, 14197 Berlin, Germany; E-Mails: ezavalap@zedat.fu-berlin.de (E.Z.-P.), \\ manuel.gongora@fu-berlin.de (M.G.-M.) \\ * Corresponding author
}

Submitted: 26 October 2015 | Accepted: 18 February 2016 | Published: 19 April 2016

\begin{abstract}
Latin America is experiencing today the greatest religious diversity in its entire history. However, it must also be noted that a large number of the growing religious minorities may be classified into types of Christianity with conservative overtones. In this paper we will suggest that the literature streams on multiple secularities in contemporary (Western) societies and religious diversity in Latin America do offer insightful perspectives yet fail to adequately convey the challenges raised by the religious across contemporary Latin America. Addressing Latin America's historical background, we will distinguish conceptually and empirically among different degrees of secularities, diversities and pluralities and will construct with these distinctions a descriptive-normative model that can guide future analyses of secular and religious phenomena in Latin America. It is only through a comprehensive understanding of diversities, pluralities and secularities that the debates on those human rights crucial for social inclusion-from sexual and reproductive rights to gender and religious equality - can be fruitfully conducted in and beyond Latin America.
\end{abstract}

\section{Keywords}

Christian hegemony; multiple secularities; pluralism; religious diversity

\section{Issue}

This article is part of the issue "Religious Diversity and Social Inclusion", edited by Gary Bouma (Monash University, Australia).

(C) 2016 by the authors; licensee Cogitatio (Lisbon, Portugal). This article is licensed under a Creative Commons Attribution 4.0 International License (CC BY).

\section{Introduction}

Different realities require different analytical approaches and policy responses. Latin America, ${ }^{1}$ like any other macro-region, has a complex religious history, ranging from the colonial predominance of Catholicism between the $16^{\text {th }}$ and $19^{\text {th }}$ centuries to a manifest multiplicity of religions in the last decades. However, whereas other world regions might have similar histo-

\footnotetext{
1 In this paper the term "Latin America" encompasses only Spanish and Portuguese-speaking countries on the mainland. The Caribbean requires a separate analysis due to its diverse historical experiences (e.g. the Cuban path towards state atheism in the aftermath of the Revolution).
}

ries of colonial evangelizing regimes and comparable landscapes of religious diversity, the complexity of the Latin American experiences cannot be equated with the complexity of those regions' religious histories and configurations. In this paper we argue that perspectival biases in the idea of multiple secularities and conceptual inaccuracies in the analysis of religious diversities in Latin America may be contributing to misunderstandings of the challenges associated with social inclusion that the region faces today.

Firstly, we will offer a legal historical overview of Latin America's colonial background. We will argue that such a background and its religious dogmatism cannot be neglected in comprehensive accounts of contemporary religious issues in Latin America. In our view, such 
accounts must also include reflections about the fact that the growing religious minorities in Latin America are mostly Christian minorities. We will then address the literature that deals with "multiple secularities" across the globe and the literature that analyses religious diversity in Latin America. We will point out the former's underrating of post-colonial cases and the latter's conceptual imprecisions regarding Christian minorities, religious diversity and pluralism. Our analysis will suggest how these gaps are detrimental to the understanding of secular and religious phenomena in Latin America. After these preparatory discussions, we will present a descriptive-normative analytical model that can be used to provide a more comprehensive understanding of the complexity of the religious fields in Latin America and their multiple degrees of secularities, diversities and pluralities. We will conclude with the observation that, by identifying and reflecting upon those complexities and degrees, it is possible to discuss with more precision the impact of religious phenomena on human rights and, by extension, on social inclusion.

\section{Religious Diversity in Latin America: A Legal Historical Overview}

In 1493 (shortly after receiving news about the West Indies), the Pope granted to the Spanish kings the administrative control of the Catholic Church in the new territories, later confirming this decision with the Papal Bulls of 1501 and 1508; in 1514 he extended this privilege to the Portuguese kings. The system was called Royal Patronage (Patronato Real or Padroado Real). Iberian crowns enjoyed the prerogative of appointing bishops in their colonies; hence, the civil and ecclesiastical administrations often overlapped. The Iberian empires throughout the colony banned non-Catholic religions (particularly Judaism, Islam and Protestantism) in the Americas with relative success. The Spaniards adopted a cross-and-sword policy of expulsion and forced Christianization in both the Iberian Peninsula and the Americas (Prien, 2013, pp. 3-11). Small numbers of Jews and Muslims fled to America after being expelled from Spain (1492) and Portugal (1497), but many of them converted to Christianity to avoid persecution from the Inquisition. A few native peoples (e.g. Cunas, Mapuches, Amazonian Indians) managed to escape from Iberian rule and were able to maintain, to a great extent, their cultural identity; similarly, Africans who escaped slavery and formed autonomous settlements could partially preserve their religious traditions. But most African and indigenous peoples (were) converted to Christianity-though some of their beliefs and religious practices remained, hidden, through syncretism (Rauhut, 2012). The absence of competing religions resulted in an absolute religious intolerance. While in Europe the Augsburg principle cuius regio, eius religio could not be effectively enforced, leading to a proliferation of edicts of religious tolerance throughout the continent, the Iberian empires in America implemented the Inquisition's goal of the systematic control and extermination of sects, heretics and nonbelievers (Chuchiak, 2012). The region became the ultimate expression of the Iberian Counter-Reformation and was unable to develop any significant form of social conviviality with other religions for almost four centuries.

After the wars of independence (early $19^{\text {th }}$ century), relations between church and state became a central dispute between the emergent political factions: liberals, who usually advocated for religious tolerance and encouraged secular authorities, and conservatives, who aligned themselves with the Catholic Church as a rule. Although liberals dominated the new governments, they were aware that religion was a powerful force for social cohesion in the effort to build a national identity in the political chaos of the postindependence era. Thus, they assured the clergy that the Catholic Church would preserve its privileges. As a matter of fact, all the new nations were confessional states, and the Roman curia was forced to allow the new countries patronage rights (Prien, 2013, pp. 277278, 291-297). All Latin American Constitutions of the early nineteenth century declared their unrestricted, and in some cases perpetual, devotion to Catholicism as the state religion; in some cases, even private worship in other faiths was banned. ${ }^{2}$ All Latin American Constitutions adopted shortly after the Spanish Reconquista and restoration (1814-1820) maintained confessional clauses, excluding any other religion. ${ }^{3}$ Two centuries later, Costa Rica remains as the only confessional State in Latin America. Non-confessional constitutions in the mid-nineteenth introduced freedom of worship and religious tolerance, allowing missionary Protestantism and immigration by Protestants, ${ }^{4}$ especially in Brazil and the Southern Cone. Nevertheless, Catholicism was preserved as the state religion. ${ }^{5}$ In 1910 , at

2 Cf. e.g. Article 1 (Chapter I) of the 1811 Federal Constitution of Venezuela; Article 4 (Title I) of the 1812 Constitution of the Republic of Cundinamarca; Article 10 of the 1823 Constitution of Chile.

${ }^{3}$ Cf. e.g. Article 8 of the 1823 Constitution of Peru; Article 5 of the 1824 Constitution of the Empire of Brazil; Article 5 of the 1824 Constitution of El Salvador; Article 11 of the 1824 Constitution of the Federal Republic of Central America; Article 3 of the 1824 Constitution of Mexico; Article 45 of the 1825 Constitution of Guatemala; Article 5 of the 1825 Constitution of Honduras; Article 3 of the 1828 Constitution of Chile; Article 8 of the 1830 Constitution of Ecuador; Article 6 of the 1831 Constitution of Bolivia.

${ }^{4}$ Mostly from German-speaking countries, Denmark and the Netherlands.

${ }^{5}$ According to Prien (2013, p. 360), several constitutions granted religious tolerance, while preserving Catholicism as the state religion; for instance, in the Provincias Unidas del Río de la Plata's (1819), and later in those of Argentina (1853), Brazil (1825), Uruguay (1830), Paraguay (1870), Chile (1833) and its 
least $94 \%$ of Latin Americans were Roman Catholics; this percentage remained practically unchanged until the 1980s (Pew Research Center, 2014a, p. 26).

Today, non-confessional constitutions represent the absolute majority in the region. Nevertheless, there are notable differences, resulting from dissimilar historical paths and domestic political dynamics. Nine constitutions make at least a passing reference to God in their preambles (Argentina, Colombia, Ecuador, El Salvador, Honduras, Nicaragua, Panama, Paraguay and Peru). The concept of morals, which is invoked as a restriction on some rights and freedoms connected with religion, explicitly derives from one single religious tradition (Catholicism) in Costa Rica, Panama, and Peru. In some countries (e.g. Nicaragua, Panama, and Peru) religious instruction in public schools is based on Christian values. The right to conscientious objection to military service for religious beliefs is not recognized in several countries. In sum, when comparing Latin America's contemporary challenges associated with religious diversity and social inclusion to those in other world regions, one should consider the crucial role of the colonial experience in understanding the absolute predominance of one religion to the exclusion of any other; this background yielded divergent secularization processes, with specific regional and national paths, dynamics and targets.

\section{Religious Diversity in Contemporary Latin America}

Latin American nominal Catholics amount to nearly $40 \%$ of the world Catholic population (Pew Research Center, 2014a, p. 4; Parker, 2005, p. 36). However, the percentage of people identifying as Catholic has fallen significantly. According to Latinobarómetro (2014, p. 4), the percentage of Roman Catholics fell from $80 \%$ in 1995 to $67 \%$ in 2013. A recent report by the Pew Research Center (2014a, p. 14) suggests that there are some countries in Latin America whose nominal Catholics may amount to half (El Salvador, Guatemala, Nicaragua) or less than half (Honduras and Uruguay) of the total population. Atheism, however, has not necessarily increased. ${ }^{6}$ The emergence of non-Catholic religions and organizations in Latin America has been acknowledged and studied in a number of works by social scientists (e.g., Beltran, 2011; Bidegain \& Demera, 2005; De la Torre \& Gutiérrez, 2007, 2008; Fediakova, 2007; Ferre, Gerstenblüth, \& Rossi, 2009; Forni, Mallimaci, \& Cárdenas, 2003; Freston, 2011; Garma, 2007; Garvin, 2005; Parker, 2005, 2012). In these works the concept of religious diversity has been put forward as an unmis-

Ley Interpretativa (1865), Bolivia (1906), Peru (1915), Venezuela (1874), Honduras $(1848,1865,1873)$ and Costa Rica (1860).

${ }^{6}$ In countries like Chile and Uruguay, however, the numbers of atheists, agnostics and religiously unaffiliated has remarkably increased (Pew Research Center, 2014a). takable fact in contemporary Latin America. The religious predominance that Catholicism enjoyed until the second half of the twentieth century has indeed been challenged by expanding religious minorities.

However, there is a factual particularity that is worth pointing out. The growing non-Catholic minorities in Latin America are mostly Christian ${ }^{7}$ minorities. Describing Latin America as "the world center of Christianity" (Freston, 2012, p. 80; our translation) might perhaps be an over-statement, but it is an unequivocal fact that the majority of the non-Catholic minorities spreading across Latin America are historical or emergent forms of Protestantism. In this sense, we observe two complimentary processes of religious migration: an inter-American flow of religious denominations and a conversion from Catholicism to Protestantism. The former is a process that spreads from the United States and Brazil towards the rest of the continent. Apart from the historical Protestants who arrived starting in the $19^{\text {th }}$ century, the first agents of this migration wave were U.S. missionaries who were no longer allowed to travel to China after 1949 and were sent instead to Latin America (Prien, 2013, p. 553). With the exception of Uruguay, a wide spectrum of Anglo-American denominations has achieved a remarkable presence in all Latin American countries, in particular, in Brazil and Central America (Table 1); these include Baptists, Pentecostals, Presbyterians, Methodists, and Adventists. Additionally, several Brazilian Pentecostal and neo-Pentecostal churches have also penetrated the Andean region and other Latin American countries-e.g. the Igreja Universal do Reino de Deus and Deus é Amor.

It could be said that the migration process above is being consolidated or extended through a complimentary process of conversion. That is, current religious minorities are also the result of individuals who decide to convert (Freston, 2012) to another Christian religion. At least a third of current Protestants were raised as Catholic and half or more say they were baptized as Catholics. Interestingly, $60 \%$ of converts to Evangelicalism said that one reason they left the Catholic Church was their desire for a more assertive teaching on moral questions and greater commitment, reflected in conservative positions on typical hot-button issues (Pew Research Center, 2014a, pp. 5-6). The resulting religious landscape is a particular one.

If figures from the latest survey by the Pew Research Center (2014a) are considered, only $8 \%$ of the total population in Latin America would be religiously unaffiliated, and $88 \%$ would be Christian (19\% Protestants and $69 \%$ Catholics). Results from the World

\footnotetext{
${ }^{7}$ By referring to this comprehensive category, we want to convey not an idea of hierarchical "varieties" of a single religion (Catholicism) but their theological, ritualistic and socio-political coincidences-regardless of whether these are seen as derivative or independent.
} 
Table 1. Percentage of Catholics and Protestants.

\begin{tabular}{llllll}
\hline & Country & $\begin{array}{l}\text { Estimated Population } \\
\mathbf{2 0 1 3} \text { (millions) }\end{array}$ & Catholics & $\begin{array}{l}\text { Protestants/ } \\
\text { Evangelicals }\end{array}$ & $\begin{array}{l}\text { Total } \\
\text { Christians }\end{array}$ \\
\hline Countries with & Paraguay & 6.6 & $90 \%$ & $6 \%$ & $96 \%$ \\
absolute Catholic & Mexico & 116.2 & $83 \%$ & $5 \%$ & $88 \%$ \\
dominance (>70\%) & Peru & 29.8 & $81 \%$ & $13 \%$ & $94 \%$ \\
& Ecuador & 15.4 & $80 \%$ & $11 \%$ & $91 \%$ \\
& Colombia & 45.7 & $80 \%$ & $14 \%$ & $94 \%$ \\
& Bolivia & 10.5 & $78 \%$ & $16 \%$ & $94 \%$ \\
& Argentina & 42.6 & $76 \%$ & $5 \%$ & $81 \%$ \\
\hline Countries with & Panama & 3.6 & $75 \%$ & $20 \%$ & $95 \%$ \\
significant & Chile & 17.2 & $70 \%$ & $15 \%$ & $85 . \%$ \\
Evangelical influence & Costa Rica & 4.7 & $64.6 \%$ & $22 \%$ & $86.6 \%$ \\
(>20\%) & Guatemala & 14.4 & $63 \%$ & $23 \%$ & $86 \%$ \\
& Nicaragua & 5.8 & $59 \%$ & $36 \%$ & $95 \%$ \\
\hline Countries without & El Salvador & 6.1 & $53 \%$ & $28 \%$ & $81 \%$ \\
religious dominance & Honduras & 8.4 & $51 \%$ & $33 \%$ & $84 \%$ \\
\hline
\end{tabular}

Source: Bureau of Democracy, Human Rights and Labor, U.S. International Religious Freedom Report for 2013.

Table 2. Percentage of Christians and non-Christians.

\begin{tabular}{llllllll}
\hline Affiliation/Country & Argentina & Brazil & Chile & Colombia & Ecuador & Peru & Uruguay \\
\hline Total Christians* & 71.2 & 78.9 & 75 & 77.1 & 76.1 & 86.8 & 31.2 \\
Total non-Christians & 10.9 & 5.6 & 0.2 & 1.1 & 0.3 & 1.7 & 7.5 \\
$\quad$ Other; Not specific & 9.7 & 1.2 & 0 & 0.9 & 0.3 & 1.4 & 7.3 \\
$\quad$ Spiritist & 0 & 3.5 & 0 & 0 & 0 & 0 & 0 \\
Espirit, candomble, & 0 & 0.5 & 0 & 0 & 0 & 0 & 0 \\
umbanda, esoterism, & & & & & & & \\
occultism & & & & & 0 & 0 \\
Buddhist & 0.5 & 0.2 & 0 & 0.1 & 0 & 0.2 & 0 \\
Hindu & 0.2 & 0 & 0.1 & 0 & 0 & 0 & 0.2 \\
Jew & 0.3 & 0.1 & 0.1 & 0 & 0 & 0.1 & 0 \\
Muslim & 0.2 & 0.1 & 0 & 0.1 & 0 & 0.1 & 60.7 \\
None & 16.9 & 15 & 23.1 & 21.4 & 23.5 & 10.1 \\
Don't know/No answer & 0.9 & 0.6 & 1.7 & 0.3 & 0.1 & 1.5 & 0.6 \\
N= & 1,030 & 1,486 & 1,000 & 1,512 & 1,202 & 1,210 & 1,000 \\
\hline
\end{tabular}

Source: Adapted from figures obtained through World Values Survey's online-analysis tool, wave 6, 2010-2014. * Roman Catholics, Protestants, Christians, Evangelicals, Pentecostals, Jehovah Witnesses, Mormons, 7th Day Adventists and Orthodox.

Values Survey are somewhat more conservative, but the pattern is also noticeable. Table 2 presents the most recent figures (waves 2011-2014) from the World Values Survey on religious denominations in some countries in Latin America. Although there are exceptional cases like Uruguay, this survey suggests that more than $70 \%$ of the population in Latin America is nominally Christian even in countries such as Argentina and Brazil, where non-Christian minorities are comparatively significant.

If the figures in Table 2 are compared, for example, to the more even distribution in the Asia-Pacific zone of Christians (7\%), Muslims (24\%), Unaffiliated (21\%), Hindus (25\%), Buddhists (12\%), Folk religions (9\%),
Other religions (1\%) and Jews (<1\%) (Pew Research Center, 2014b), it is possible to state that the "religious diversity" label might have been used in Latin America too liberally and without the necessary nuances. Granted, the unique institutional/group identity, the doctrinal-theological specificities, and the particular socio-political histories of Christian minorities - as well as the diversity within Catholicism ${ }^{8}$ - must be acknowl-

${ }^{8}$ Catholicism, as a global religion, is not only a mirror of the diverse societies where it can be found (Levine 2014), it also comprises a number of sub-institutions (e.g. religious orders, convents, schools, charities, etc.) and hierarchical structures (e.g. parishes, dioceses, bishoprics) whose direction by different individuals or groups across a multiplicity of historical peri- 
edged and carefully reflected upon. However, it would be misleading to assume that there are no similarities between some of these minorities' theological principles and moral-political stances and those found in Latin America's Catholicisms. From a global perspective, Latin America still exhibits low levels of diversity, comprising, as it does, a majority of Christian, mostly conservative, confessions. Notwithstanding the theological antagonisms and mutual distrust among Protestants, Evangelicals and Catholics, it is not unusual to find coinciding conservative stances among them on social issues such as marriage, family, sexual orientation, reproductive choices, gender relations, education and personal autonomy. In these areas crucial for social inclusion one could speak of a Christian hegemony. This is characterized by the persistence of unequal rules of the game in the religious market; high control by churches over the educational system; promotion of traditional (Christian) values and views on personal autonomy (which leads to discrimination in workplaces and in schools, for instance); legitimation of sexism, homophobia, transphobia and other forms of discrimination; and/or the criminalization of abortion and stigmatization of women. From a legal point of view, such a framework creates inconsistencies with international human rights standards.

From this brief overview we can conclude that Latin America's religious fields diverge from those in the U.S. and Europe, where challenges arise instead from large waves of immigrants bringing with them their Christian and non-Christian religions. Similarly, Latin America's challenges are not those of African and Asian states, which have adopted Islam as an official religion and where minority faiths are discriminated against, conversion is punished, and several forms of religiousrelated violence are common. The challenges in Latin America are different. While all Latin American countries ban religious discrimination, recognize religious freedom, and protect indigenous religiosity, most of them remain countries where Christian denominations prevail and where religious equality is far from being achieved outside of constitutional texts.

\section{Perspectival and Conceptual Shortcomings}

In our view, there are two sets of literature on secular and religious diversities that are crucial to understanding Latin America's religious fields. The first offers a comparative framework of multiple secularities across the globe; and the second refers to the religious diversity/pluralism in Latin America. We will argue that there are critical shortcomings in both sets and also potential contributions between them if those very shortcomings are worked out. We will argue that multiple-

ods and world regions yields greater diversity in performative and ideological terms. secularities approaches do not necessarily overcome the west-and-rest discourse and can be further improved by considering the case of Latin America, yet without the conceptual overlapping between the ideas of religious diversity, plurality and pluralism that can be found in some scholarly works on this region.

Modernity in the west-and-rest discourse is conceived as a European innovation that has been globally transferred and whose European standards are the arrival point of every modern society (Hall, 1996). For decades, postcolonial authors have deconstructed this discourse (Boatcă, 2015, pp. 201-226; Costa, 2006, pp. 83-97; see also Bhambra, 2007; Chakrabarty, 2000). Recently, some debates on secularisms and religious diversity have considered the postcolonial critique of Occidentalism and have adopted a "multiple modernities" approach. A group of scholars, for instance, has proposed a model of "multiple secularities" which "acquire different shapes in different countries", for they operate "according to different cultural logics that document specific social histories of conflict"; these secularities, in a sense, "'respond' to specific.... reference problems and offer 'solutions' to them" (Schuh, Burchardt, \& Wohlrab-Sahr, 2012, p. 358; see also Wohlrab-Sahr \& Burchardt, 2012). In a later publication, Burchardt, Wohlrab-Sahr and Middell (2015) accounted for these problems and distinguished four analytically ideal (not normative) types of secularities (see Table 3).

Table 3. Multiple secularities.

\begin{tabular}{ll}
\hline Reference Problems & $\begin{array}{l}\text { Ideal types (Secularity for } \\
\text { the sake of...) }\end{array}$ \\
\hline $\begin{array}{l}\text { Individual freedom vis- } \\
\text { à-vis dominant social } \\
\text { units }\end{array}$ & $\begin{array}{l}\text {...individual rights and } \\
\text { liberties }\end{array}$ \\
$\begin{array}{l}\text { Religious } \\
\text { heterogeneity and the } \\
\text { resulting potential or } \\
\text { actual conflictuality }\end{array}$ & $\begin{array}{l}\text {...balancing/pacifying } \\
\text { religious diversity }\end{array}$ \\
$\begin{array}{l}\text { Social or national } \\
\text { integration and } \\
\text { development }\end{array}$ & $\begin{array}{l}\text {...societal or national } \\
\text { integration and } \\
\text { development }\end{array}$ \\
$\begin{array}{l}\text { Independent } \\
\text { development of }\end{array}$ & $\begin{array}{l}\text {...the independent } \\
\text { institutional domains }\end{array}$ \\
\hline
\end{tabular}

Source: Own elaboration based on Burchardt et al. (2015).

To these four problem-secularity type combinations the authors add four accompanying groups of "guiding ideas": freedom and individuality, toleration and respect, progress and modernity, and rationality and autonomy, respectively. These guiding notions are normative "reference point[s]" that legitimize "religious- 
secular distinctions" (Burchardt, Wohlrab-Sahr \& Wegert, 2013, p. 615) and are held by individuals, groups, states or functional domains. We agree with the authors as to the convenience of separating the notion of the secular from linear narratives of modernity and underlining the historically contingent meanings of the secular and the different starting and arrival points of the societies studied. We also prefer the concept of "secularity" over "secularism" (which is usually restricted to the relationships between organized religions and the state) as a way to extend the analysis to the relations between the triad of state, organized religions, and society with its functional domains, e.g. education, science, media, business. In this sense, the concept serves to remedy what Frigerio and Wynarczyk call the "dominant model" $(2008$, p. 248$)$ in analyses of religious fields-the exclusivist emphasis on the churches and the state alone that can be found in the specialized literature on Latin America (e.g. Amuchastegui, Cruz, Aldaz, \& Mejia, 2010; Blancarte, 1994; Levine, 2009; Masferrer, 2013; Moran, 2013; Parker, 2012; Sawchuck, 2004) and beyond (e.g. Lavinia \& Turcescu, 2011; Robbers, 2005). Nevertheless, this model may not overcome the west-rest bias. The groups of "guiding ideas" in each combination above are analytically useful but include complex concepts which, at least in some post-colonial societies, constitute implicit or explicit (quasi)epistemologies-e.g. progress, modernity and rationality-that have guided secular and non-secular individuals, states, groups and functional domains alike in a variety of projects, controversies and disputes. It is therefore not surprising that the authors find difficulties in inserting the case of South Africa into their model. They acknowledge that whereas modernity in the West meant a "struggle between Christianity and secularizing and secularist forces," Christianity in South Africa "became fundamentally intertwined with modernity" (Burchardt et al., 2013, p. 621). What would happen then to the model if it were constructed from the outset with this type of "exceptional" (postcolonial) cases? The case of Latin America is a useful one because it represents, first off, a region where "cultures of secularity" (Wohlrab-Sahr \& Burchardt, 2012, p. 888) as well as religious cultures and phenomena-emerging religious minorities includedfill the social landscape and the discursive space.

However, in our view, some scholarly debates about Latin America's religious diversity do not necessarily offer a sound analytical platform upon which an alternative model-aimed at understanding not just multiple secularities but multiple religious phenomena beyond those of the West-could be constructed. In some scholarly works on Latin America's religious phenomena the concepts of diversity, plurality and pluralism are used interchangeably either as descriptors of the simultaneous presence of different religious denominations or as counterparts to concepts such as re- ligious monopoly, hegemony, uniformity or majority. For instance, in a work on religious diversity in Latin America, an author asserts that "there is already a Latin American religious pluralism which is based in a growing diversity of heterogeneous cultural expressions." Later on, however, he explains this "religious pluralism" by referring circularly to the "diversity of beliefs" (Garma, 2007, p. 50). In a major work on religious diversity in Mexico, the introductory chapter points to the need to study the scope of "the diversification and the religious plurality" in Mexican indigenous localities (De la Torre \& Gutiérrez, 2007, p. 14), thus implying the occurrence of two different realities, yet no conceptual distinction between these two concepts is provided in the text-instead the terms religious pluralism, plurality, diversity and diversification seem to be used interchangeably $(2007$, pp. $7,9,11,14,15)$. Similarly, in an introduction to a co-edited volume on religious diversity in Colombia, "religious plurality" is accounted for by the "religious diversity" (African religions, Sephardic Judaism, Islam) reportedly found in Latin America during colonial and postcolonial times (Bidegain, 2005, p. 15).

These conceptual-analytical imprecisions have been pointed out by other authors. Frigerio and Wynarczyk (2008) refer to the importance of Beckford's conceptual distinction between pluralism as i) "the magnitude" of religious diversity, ii) the extent to which religious minorities are "accepted" in a society and iii) the acknowledgement of the "moral and political value" of religious diversity (2008, pp. 233-234). In the view of these authors, the mere presence or growth of religious diversity does not necessarily equate to pluralism in sense ii) and, more importantly, in sense iii), that is, pluralism as the positive sanction of the moral and political relevance of new religious expressions and organizations. For pluralism to exist, the authors assert, there must be a fair "regulation" of the "religious market" (2008, p. 248), where the state as well as non-state institutions, such as NGOs and mass media, sanction the extra-religious importance of religious minorities. Frigerio and Wynarczyk's conceptual distinctions are similar in principle to Levine's. Levine (2009) distinguishes between religious plurality and religious pluralism. The former equates to the existence of religious diversity, that is, the quantitative presence of religious groups, denominations, and churches; religious pluralism goes beyond this presence and amounts to "the construction of rules of the game" (2009, p. 407; see also Freston, 2012, pp. 87-88) that give equal rights and legitimacy to the newcomers in the religious field. For Levine plurality serves as a necessary, though insufficient, condition of pluralism. From a stronger normative position, Eck (2001) had suggested earlier a similar clarification of religious pluralism. For this author, as well, religious pluralism does not amount to religious diversity. Firstly, whereas religious diversity is just "an observable fact," religious pluralism, in the author's view, must be "real engagement" with the re- 
ligious other; secondly, whereas religious diversity entails only tolerance, religious pluralism also demands the understanding of the religious other and the overcoming of "stereotypes and prejudices"; thirdly pluralism must not become "valueless relativism" but must rather strengthen "the health of religious faith" (2001, pp. 6971). Eck notes as well that pluralism does not refer to a given state of affairs but to "the ongoing work of each generation" (2001, p. 72).

With the above shortcomings and conceptual guidelines in mind, we now propose an analytical frame focused on the concrete hegemonic framework of Latin America and the conceptual distinctions between, and degrees of, secularities, diversities and pluralities.

\section{A Three-Dimensional Model of Religious Pluralisms}

In this section we describe both a series of key dimensions and a scale of degrees by which those dimensions can be analysed and referred to in debates on religious diversity, religious plurality and social inclusion, as depicted in Figure 1.

Firstly, we propose three key dimensions as axial categories that represent, in our view, the most important subfields in a given region's religious field/s: society, organized religions and the state. What we suggest is to regard them as institutions but also as in- terdependent sub-fields of forces; that is, partly autonomous and partly dependent axial spaces where symmetric and asymmetric relations of power between individuals, groups and institutions take place either in manifest or latent forms (Lukes, 2005). By referring to them as currently existing sub-fields we do not mean clear-cut spaces whose analysis concerns only presenttime phenomena. These are dimensions whose constitution is to varying degrees related to their historicity. Thus we understand the organized religions dimension as one of the religious field's subfields, where historical churches and emergent organized religions and syncretic cults can be found either separate from each other or connected through symmetric or asymmetric links. In the same fashion, we suggest looking at the state not as a macro-institution but as a dimension where struggles for, and the granting of, religious rights take place. Similar to Frigerio and Wynarczyk's proposal (2008), our axial spaces include the society dimension. Yet we do not understand "society" as particular organizations and mass media that regulate the religious market (2008, pp. 228-229), but more generally as a subfield that is constituted by a wide range of individuals and groups that interact or not in a given context and can range from the atheist or the nonbeliever to the religiously-unaffiliated and the religiously-(multi)affiliated.

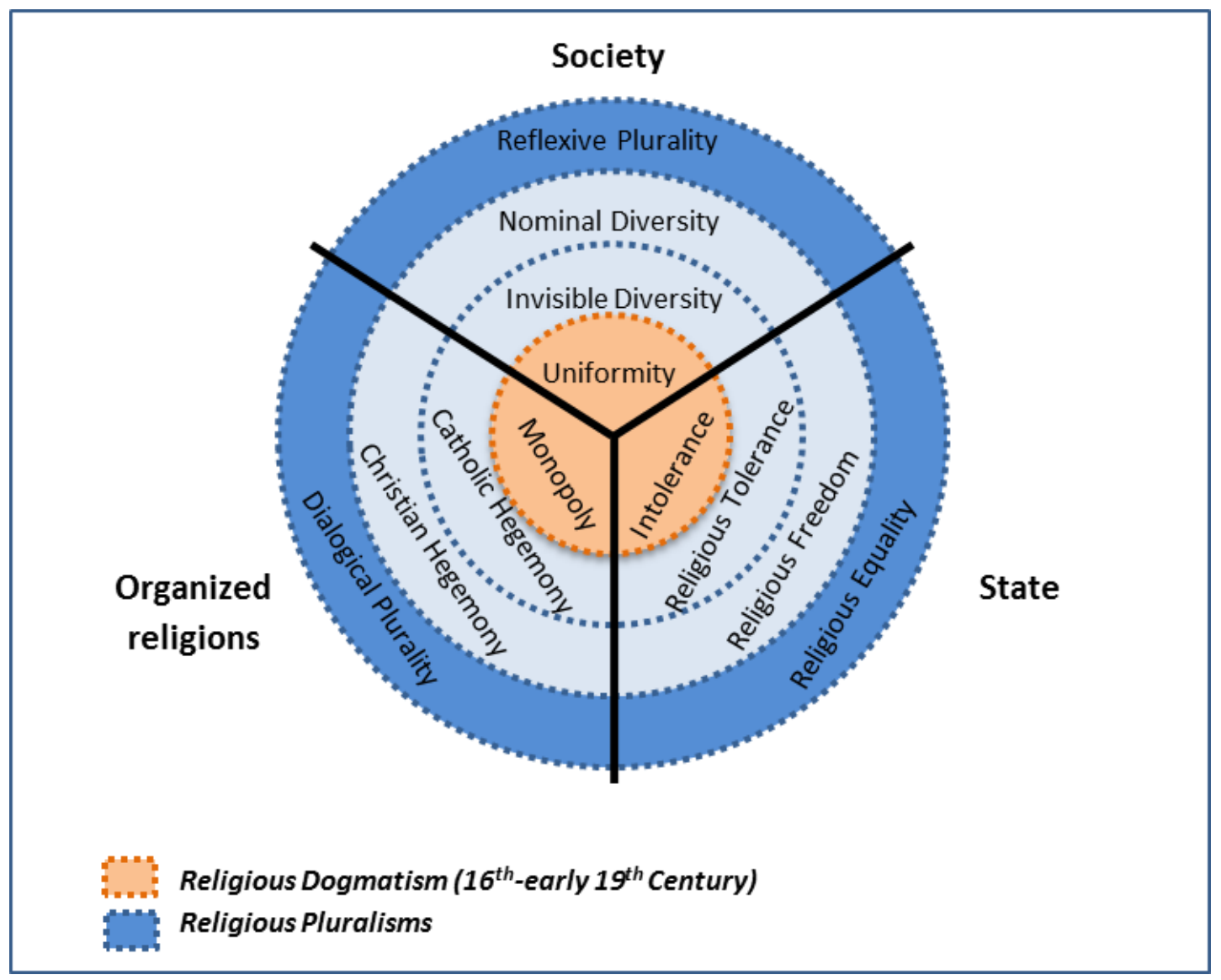

Figure 1. A three-dimensional model of religious pluralisms. 
The second particularity of our model is aimed at overcoming the implicit and explicit binarisms in the literature on the emerging religious diversity in Latin America by adding degrees which can further qualify the three dimensions above. Like Eck (2001), Frigerio and Wynarczyk (2008) and Levine (2009), we sustain the analytical relevance of distinguishing between the quantitative emergence of religious diversity, the configuration of religious plurality, and religious pluralism as a combined and ceaseless process. Following this logic, instead of conveying in our model the idea of societies that are "uniform" or "diverse" in terms of religious (un)affiliation; "hegemonic" or "plural" in the subfield of organized religions, and "confessional" or "secular" with regard to the state, we want to convey multiple degrees of diversity, plurality and secularity that can be found in society, organized religions and state dimensions respectively. These degrees are not cumulative stages towards religious pluralisms; they are societal features that do not, and should not, necessarily unfold sequentially. Each degree is meant to be analysed qualitatively, quantitatively or both, to assess how much of, and which specific manifestations of, the degree in question can be empirically verifiable in a given case. We consider it important to point out as well that the degrees, which we will expand on below, are based mostly on descriptive analytics but also on a cautious normative standpoint, upon which a flexible concept of ideal religious pluralisms will be conveyed. These ideal religious pluralisms amount to the degrees illustrated in Figure 1's outer circular layer and are based on the idea that complete and permanent harmony, ecumenism and cooperation in societies (Mouffe, 2000) and religious fields might stand as desirable teleologies and even practical goals but should not be regarded as necessary requirements for a sound religious pluralism. We will expand on these realistic expectations in the sub-sections below.

\subsection{The State Dimension}

As observed, secularity in Latin America mainly relates to the state protection of the rights of religious minorities and the demise of the institutional privileges enjoyed by the Catholic Church, rather than to the decline of religiosity or the retreat of religion from public spaces. Due to the secular paths taken in Latin America (i.e. usually from Catholic confessionality to impartial but non-atheist states) we basically distinguish between: 1) religious intolerance: confessional states where nonadherents to the state religion are socially excluded and even private non-Catholic worship is expressly forbidden, creating favorable conditions for structural discrimination against persons who do not accept the official ideology or who oppose it; 2) religious tolerance: confessional states where religious minorities, although being socially excluded to different extents, are allowed (rather than entitled) to hold religious ceremonies in public, and the Catholic Church is supported by the government and enjoys other legal and political prerogatives; 3) religious freedom: confessional and non-confessional states that recognize the freedom to choose a religion or belief, consistently maintain a certain church-state separation and allow the legal recognition of non-Catholic religions (including their rights to possess properties, land and media; to form political parties; and to declare political positions), but where the Catholic Church might retain some privileges in consideration of its majoritarian status or cultural relevance for the nation; and 4) religious equality: non-confessional states that revoke the Catholic Church's privileges and establish principles of state evenhandedness vis-à-vis theistic, non-theistic and atheistic beliefs.

\subsection{The Society Dimension}

We suggest qualifying the degree of religious heterogeneity in society by contrasting the previous religious uniformity of Latin American colonial societies with their contemporary diversity and by breaking down the latter into a) invisible diversity, b) nominal diversity and c) reflexive plurality. Our starting point is the idea that a plural society should first and foremost know about the actual existence of the religious alternatives that can actually render that society plural. By proposing invisible diversity as an analytical distinction, we want to bring attention to the fact that there have been, and surely still are and will be, non-Catholic individuals and groups in Latin America whose religious or nonreligious profile is unknown beyond limited circles of state and/or religious experts. When the religious others' local presence is ignored by the majority of individuals and major groups (e.g. media, educational institutions, business, political parties, civic organizations, etc.), we can speak about a situation of invisible diversity. Individuals and groups in one of Mexico's westerncentral states may be aware of the presence of publicly active Jehovah's Witnesses in the vicinity but individuals at large, and perhaps the local media or business sector, might not necessarily know about the presence of members of the "Marian Trinitarian Spiritualism" church (Sanchez, 2009). In such a case quantitative and qualitative assessments of what/how much religious diversity has been detected in a region can give a better sense of how much invisible diversity prevails there.

By nominal diversity we mean societies where there is both a factual presence of religious minorities as well as some major institutions, and/or individuals within those institutions, that do know about the presence and basic constitution of alternative religions and religious groups in that society. These are social institutions and individuals, beyond limited circles of religious or state experts, which are relatively knowledgeable about general facts of those religious alternatives- 
their main doctrinal tenets or organizational characteristics, for instance. Within this category it is also possible to distinguish between a) actively hostile scenarios-where religious minorities are discriminated against or attacked (Dias, 2012; Vallverdu, 2005, p. 62); and b) passive scenarios-where individuals affiliated to the majority religion are aware of the presence and basics of the religious others but have little or no desire to understand them further - and vice versa (Mendoza, 2008, p. 202).

We suggest reserving the term reflexive plurality for societies where individuals from different religious groups-as well as atheists-know about the presence, the basics and at least some of the substantial views and background of their religious counterparts. These societies may or may not enter into cooperative relations based upon such knowledge. We do not see societies with reflexive plurality from a radical idealistic viewpoint, that is, as perfect societies where everybody knows with precision the history and doctrinal configuration of each religious alternative and where cooperation is therefore the norm (cf. Eck, 2001). For us, reflexive plurality does require openness and tolerance in order to be aware of prejudice (Eck, 2001), but such an openness can well remain as the base of a detached understanding.

\subsection{The Organized-Religions Dimension}

As to the plurality of churches and other organized religions, Latin America is characterized by the historical monopolistic position of the Catholic Church. In some cases, this monopoly remained uncontested even after the post-independence secular reforms that took place at different points in time across the region. What has followed, after the nominal challenge of this monopoly over the last two centuries, are different types of nonmonopolistic dimensions of organized religion. From a descriptive position we distinguish two types: Catholic hegemony and Christian hegemony; from a normative position we distinguish one further type: dialogical plurality. Catholic hegemony describes dimensions where the Catholic Church, as an internally-diverse majority church in most countries, co-exists with Christian minority churches as well as other religious groups, associations or communities whose collective identity is not necessarily that of a church (as in the case of the Umbanda; Prandi, 2004, p. 229). Notwithstanding this coexistence, the Catholic Church and its ensemble of religious orders, Catholic groups and associations retain a clear religious and extra-religious (political, cultural, educational) pre-eminence (Levine, 2014; Levy, 1996). This Catholic hegemony is better apprehended if it is seen as the outcome of the historical religious and extra-religious activism of this church and its organizations. Regarding the case of Argentina, Carbonelli and Jones refer to such an outcome as a "cultural matrix" that has the capacity "to confer meaning on national identity and to shape state structures" (2015, p. 160; our translation).

Similar to a duopoly, a Christian hegemony could be described as a religious field where the Catholic Church and Christian denominations share a dominant position, which can result from various forms of cooperation or unintended alignment on moral and extrareligious issues (e.g. against reproductive rights, homosexuality, same-sex marriage, euthanasia, etc.). Through extra-religious activism, direct intervention in politics and the operation of media channels and radio stations, Christian morals, values and worldviews thus continue to shape social relations and define the rules of the game. Brazil illustrates this case. According to Freston (1998), Brazilian Pentecostal churches-which themselves seek a hegemony within the Brazilian Protestant milieu-tend to have no united political front but do have an active presence in the country's politics. Brazilian Pentecostal politicians have been elected as governors, federal deputies and city officials; in the most recent legislative period, they accounted for $12 \%$ of the seats in the Brazilian Congress (Machado \& Burity, 2014, p. 601).

Dialogues are a main component of what we consider as an organized-religions dimension with dialogical plurality. This is a plurality that describes religious fields where majority and minority religions and religious groups not only value (Frigerio \& Wynarczyk, 2008) their different or similar contributions to the religious and extra-religious dimensions but do so by openly communicating with each other (Vallverdu, 2005 , p. 63). This particular type of religious plurality may include interfaith dialogues as well as other (sociopolitical) dialogues among the religious denominations' lay members or non-"authorized" voices (Levine, 2009, p. 406). Nevertheless, dialogical plurality, just as reflexive plurality in the society dimension, is not necessarily expected to produce cooperative engagement (cf. Eck, 2001) or a harmonious ecumenism (cf. Hagopian, 2009; Parker, 2005). Even less are such dialogues likely to be an effective means of overcoming asymmetries of power. Nonetheless, we consider dialogues as conducive to the creations of conditions of competence, dissent and negotiation that may well contribute significantly to progress towards more inclusive rules of the game. Here Frigerio and Wynarczyk's notes on the role of social institutions are relevant. A sound level of dialogical plurality is manifested when majority and minority religions/religious groups alike are able to dialogue, under equal conditions of openness, with state institutions as well as with society's civic groups, mass media, NGOs and other non-state organizations.

\section{Conclusions}

Drawing critically from the literature on religious diver- 
sity and the multiple-secularities approach, the analytical model we propose is aimed at overcoming Eurocentric categorizations and conceptual imprecisions. The model above contains both descriptive and normative analytical categories whose even and balanced distribution in Figure 1 is meant to represent neither symmetric dimensions in actual societies nor degrees of diversity, plurality and secularity that develop jointly in a linear fashion. Although the model does propose normative scenarios in the dimensions of state, religion and society, it is not meant to suggest a method which Latin American societies would have to undertake in order to develop and/or consolidate religious pluralism. The model above clarifies key concepts that can be used in specialized discussions and problematizes the interpretations of contemporary realities regarding the religious fields in Latin America. It is also a flexible analytical tool that can be adapted to local, national or transnational contexts and approaches. For instance, it can enable multi- or inter-disciplinary comparisons of degrees of secularities, diversities and pluralities that can be empirically observed across multiple local contexts-e.g. across Chiapas in Mexico, Chimborazo in Ecuador and Cauca in Colombia, where Protestant communities have apparently developed in comparable terms (Gros, 1999). Once operationalized, the model can also be used as a framework for comparative analyses of the degrees of religious pluralism across different Latin American countries or regions; these comparisons can be quantitative or qualitative and generate, for instance, indexes or typologies of religious pluralism. If the model is properly adapted-particularly the model's departure point, i.e. the region's historical backgroundit can also assist comparative analyses of the development of religious diversities/pluralisms, or other religious/secular dynamics, within and across postcolonial regions beyond Latin America. In any case, adaptations in our view would have to be cautious and preferably follow the non-Eurocentric, non-linear, complex (multiple dimensions and degrees) and realist rationale of the original model.

Above all, we consider both the discussion and the analytical proposal above to be key inputs for contemporary debates on social inclusion. As suggested in this paper, there are conceptual and empirical links between the consolidation of reflexive plurality in society at large, the development of dialogical plurality among organized religions and atheist organizations and the attainment of religious equality in terms of equal rights granted by the state to organized religions. More importantly, it can also be said that the development of reflexive and dialogical pluralities in the first two subfields may facilitate not only the consolidation of religious equality among organized religions but also the de-centering of Christian values in public education and the granting by the state of gender equality, as well as comprehensive sexual and reproductive rights for all individuals regardless of their sexual orientationsome of the crucial inclusive rights where there has been important progress on the legal and judicial fronts, but whose de facto fulfillment, and political debate at times, has been somewhat hindered by hegemonic churches and individuals' religious beliefs alike. The decrease of Catholic or Christian hegemony and the increase of dialogical plurality among organized religions, coupled with the presence of a reflexively plural society, may not be sufficient yet remains a necessary condition for the attainment of the aforementioned rights. A dialogical field of organized religions, together with societies whose reflexive plurality is high, may also facilitate the legal application and extra-legal consolidation of those inclusive rights. The resulting religious pluralisms - or the reflexive and dialogical cultures, and legal frames, of equality, understanding and dissentprovide, in principle, effective conditions for social inclusion.

\section{Acknowledgements}

We should like to thank the Social Inclusion journal's anonymous reviewers, the editor of this special issue as well as Paul Talcott and Carlos N. Mora, for their valuable comments on an earlier version of this paper.

\section{Conflicts of Interest}

The authors declare no conflicts of interest.

\section{References}

Amuchastegui, A., Cruz, G., Aldaz, E., \& Mejia, M. (2010). Politics, religion and gender equality in contemporary Mexico: Women's sexuality and reproductive rights in a contested secular state. Third World Quarterly, 31(6), 989-1005.

Beltran, W. (2011). Descripción cuantitativa de la pluralización religiosa en Colombia. Universitas Humanística, 73, 201-237.

Bhambra, G. (2007). Rethinking modernity postcolonialism and the sociological imagination. Basingstoke and New York: Palgrave Macmillan.

Bidegain, A., \& Demera, J. (2005). Globalización y diversidad religiosa en Colombia. Bogotá: Universidad Nacional de Colombia.

Blancarte, R. (1994). Iglesia y Estado en México: Seis décadas de acomodo y de conciliación imposible. México: IMDOSOC.

Boatcă, M. (2015). Global inequalities beyond Occidentalism. Farnham: Ashgate.

Burchardt, M., Wohlrab-Sahr, M., \& Wegert, U. (2013). "Multiple secularities": Postcolonial variations and guiding ideas in India and South Africa. International Sociology, 28(6), 612-628.

Burchardt, M., Wohlrab-Sahr, M., \& Middell, M. (Eds.) 
(2015). Multiple secularities beyond the West: Religion and modernity in the global age. Boston, Berlin and Munich: De Gruyter.

Carbonelli, M., \& Jones, D. (2015). Igualdad religiosa y reconocimiento estatal: Instituciones y líderes evangélicos en los debates sobre la regulación de las actividades religiosas en Argentina 2002-2010. Revista Mexicana de Ciencias Políticas y Sociales, LX(225), 139-168.

Chakrabarty, D. (2000). Provincializing Europe. Postcolonial thought and historical difference. Princeton: Princeton University Press.

Chuchiak, J. (2012). The Inquisition in New Spain, 15361820: A documentary history. Baltimore: John Hopkins University Press.

Costa, S. (2006). Dois Atlânticos. Teoria social, antiracismo, cosmopolitismo. Belo Horizonte: UFMG.

De la Torre, R., \& Gutiérrez, C. (Eds.) (2007). Atlas de la diversidad religiosa en México. México: CIESAS, COLJAL, COLEF, COLMICH, UQROO, SEGOB, CONACYT.

De la Torre, R., \& Gutiérrez, C. (2008). Tendencias a la pluralidad y la diversificación del paisaje religioso en el México contemporáneo. Sociedade e Estado, 23(2), 381-424.

Dias de Oliveira, I. (2012). Religião e etnicidade: Novas sensibilidades num mundo multicultural. In C. Parker (Ed.), Religión, política y cultura en América Latina. Nuevas miradas (pp. 285-295). Santiago de Chile: Instituto de Estudios Avanzados, Universidad de Santiago de Chile.

Eck, D. (2001). A new religious America. How a "Christian country" has become the world's most religiously diverse nation. New York: Harper Collins.

Fediakova, E. (2007). Religión, política, ciudadanía: Cambio de paradigmas, iglesias evangélicas en Chile postguerra fría. Bicentenario. Revista de Historia de Chile y América, 6(2), 71-98.

Ferre, Z., Gerstenblüth, M., \& Rossi, M. (2009). Religión y religiosidad en Uruguay. Cuadernos del CLAEH, 32(99), 19-34.

Forni, F., Mallimaci, F., \& Cárdenas, L. (Eds.) (2003). Guía de la diversidad religiosa de Buenos Aires. Buenos Aires: Biblos.

Freston, P. (1998). Pentecostalism in Latin America: Characteristics and controversies. Social Compass, 42(3), 335-358.

Freston, P. (2011). Religious pluralism, democracy, and human rights in Latin America. In T. Banchoff \& R. Wuthnow (Eds.), Religion and the global politics of human rights (pp. 101-128). New York: Oxford University Press.

Freston, P. (2012). Las dos transiciones futuras: Católicos, Protestantes y sociedad en América Latina. In C. Parker (Ed.). Religión, política y cultura en América Latina. Nuevas miradas (pp. 77-97). Santiago de Chile: Instituto de Estudios Avanzados, Universidad de Santiago de Chile.
Frigerio, A., \& Wynarczyk, H. (2008). Diversidad no es lo mismo que pluralismo: Cambios en el campo religioso argentino (1985-2000) y lucha de los evangélicos por sus derechos religiosos. Sociedade e Estado, 23(2), 227-260.

Garma, C. (2007). Diversidad religiosa y políticas públicas en América Latina. Revista Cultura y religión, 1(1), 48-60.

Garvin, N. (2005). Conversion \& conflict Muslims in Mexico. International Institute for the study of Islam in the Modern World, 15, 18-19.

Gros, C. (1999). Evangelical Protestantism and indigenous populations. Bulletin of Latin American Research, 18(2), 175-197.

Hagopian, F. (2009). The Catholic Church in a plural Latin America. In F. Hagopian (Ed.), Religious pluralism, democracy and the Catholic Church in Latin America (pp. 429-466). Notre Dame: University of Notre Dame.

Hall, S. (1996). The West and the rest: Discourse and power. In S. Hall (Ed.), Modernity: Introduction to the modern societies (pp. 185-227). Oxford: Blackwell.

Latinobarómetro. (2014). Las religiones en tiempos del Papa Francisco. Retrieved from http://www.sciences po.fr/opalc/sites/sciencespo.fr.opalc/files/LAS_RELIG IONES_EN_TIEMPOS_DEL_PAPA_FRANCISCO\%20-\%2 Ocopie.pdf

Lavinia, S., \& Turcescu, L. (2011). Church, State, and democracy in expanding Europe. New York: Oxford University Press.

Levine, D. (2009). Pluralism as challenge and opportunity. In F. Hagopian (Ed.), Religious pluralism, democracy and the Catholic Church in Latin America (pp. 405-428). Notre Dame: University of Notre Dame.

Levine, D. (2014). Popular voices in Latin American Catholicism. Princeton: Princeton University Press.

Levy, D. (1996). Building the third sector: Latin America's private research centers and nonprofit development. Pittsburgh: University of Pittsburgh Press.

Lukes, S. (2005). Power. A radical view (2nd ed.). New York: Palgrave Macmillan.

Machado, M., \& Burity, J. (2014). A ascensão política dos pentecostais no Brasil na avaliação de líderes religiosos. DADOS: Revista de Ciências Sociais, 57(3), 601631.

Masferrer, E., (2013). Religión, política y metodologías. Buenos Aires: Libros de la Araucaria.

Mendoza, M. (2008). La Nueva Jerusalén y su relación con la población otomí de Querétaro. Estudios de Cultura Otopame, 6(1), 199-211.

Moran, J. (2013). Feminismo, Iglesia Católica y derechos sexuales y reproductivos en el Chile post-dictatorial. Estudos Feministas, 21(2), 485-508.

Mouffe, C. (2000). The democratic paradox. London and New York: Verso.

Parker, C. (2005). ¿América Latina ya no es católica? Pluralismo cultural y religioso creciente. América Latina 
Hoy, 41, 35-56.

Parker, C. (Ed.) (2012). Religión, política y cultura en América Latina. Nuevas miradas. Santiago de Chile: Instituto de Estudios Avanzados, Universidad de Santiago de Chile.

Pew Research Center. (2014a). Religion in Latin America: Widespread change in a historically Catholic region. Retrieved from http://www.pewforum.org/files/2014 /11/Religion-in-Latin-America-11-12-PM-full-PDF.pdf

Pew Research Center. (2014b). Global religious diversity. Retrieved from http://www.pewforum.org/2014/04/ 04/global-religious-diversity/\#fn-20155-2

Prandi, R. (2004). O Brasil com axé: Candomblé e umbanda no mercado religioso. Estudos Avançados, 18(52), 223-238.

Prien, H. J. (2013). Christianity in Latin America (revised and expanded edition). Leiden and Boston: Brill.

Rauhut, C. (2012): Santería und ihre Globalisierung in Kuba. Tradition und Innovation in einer afrokubanischen Religion. Würzburg: Ergon.
Robbers, G. (2005). State and Church in the European Union. Baden-Baden: Nomos.

Sanchez, O. (2009). Vivir entre dos religiones. In S. Benard \& O. Sanchez (Eds.), Vivir juntos en una ciudad en transicion. Aguascalientes frente a la diversidad social (pp. 189-212). Aguascalientes: Universidad Autónoma de Aguascalientes.

Sawchuk, D. (2004). The Costa Rican Catholic Church, social justice and the right of workers 1979-1996. Waterloo: Wilfrid Laurier University Press.

Schuh, C., Burchardt, M., \& Wohlrab-Sahr, M. (2012). Contested secularities: Religious minorities and secular progressivism in the Netherlands. Journal of Religion in Europe, 5, 349-383.

Vallverdú, J. (2005). Violencia religiosa y conflicto político en Chiapas, México. Nueva Antropología, 65, 5574.

Wohlrab-Sahr, M., \& Burchardt, M. (2012). Multiple secularities: Towards a cultural sociology of secular modernities. Comparative Sociology, 11, 875-909.

\section{About the Authors}

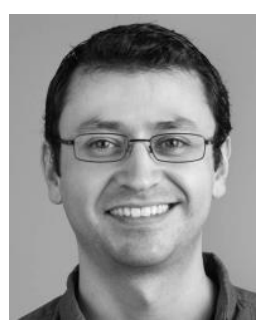

\section{Dr. Edgar Zavala-Pelayo}

Edgar Zavala-Pelayo is a postdoctoral researcher based at the Institute for Latin American Studies and the Center for Area Studies of the Free University of Berlin. He holds a master's and doctoral degree in sociology from the University of Edinburgh. His theoretical and empirical research focuses on science-and-religions and politics-and-religions entanglements and their relations to the paradigms of modernity/ies, rationality/ies and secularisms/secularities.

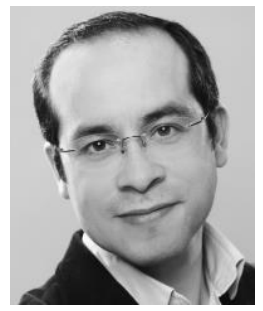

\section{Dr. Manuel Góngora-Mera}

Manuel Eduardo Góngora-Mera is a postdoctoral researcher and lecturer at the Institute for Latin American Studies of the Free University of Berlin. He obtained his doctoral degree in Public Law from Humboldt University of Berlin. His publications deal mainly with constitutional and human rights issues, including international human rights law, inter-American constitutionalism, social rights, and categorical inequalities. 